\title{
Development of Boccia Cerebral Palsy's National Athlete Achievement in the Indonesian National Paralympic Committee
}

\author{
Mustafa Al Haris', Muchsin Doewes ${ }^{2}$, Hanik Liskustyawati ${ }^{2}$ \\ ${ }^{1}$ Masters in Sports Science Program, University of Sebelas Maret, Surakarta, Indonesia \\ ${ }^{2}$ Department of Sports Science, Postgraduate Program, University of Sebelas Maret, Surakarta, Indonesia \\ mustafaalharis@student.uns.ac.id
}

\begin{abstract}
Achievement is the goal for all sports development achievements, the coaching process will affect the results that will be generated. In Indonesia, NPCI is the only organization that facilitates sports with special needs at the international level. Same with normal sports, sports with special needs also have many benefits for each athlete. Boccia is a sport with special needs for children with cerebral palsy in the world. Boccia is a precision sport that anyone can do. Disorders included such as ataxia, hypertonus, atetosis, and limitations in coordination become eligible criteria for boccia sports. The purpose of this research is to find out the fostering of the achievement of the boccia cerebral palsy national altet in the Indonesian National Paralympic Committee. This study uses a qualitative method which was carried out in two places, namely at the NPCI headquarters and the Indonesian national athlete's Boccia Cerebral Palsy Sports Hall in March 2020. Data collection techniques used interviews, observation, and documents. The technique of taking research subjects with purposive sampling with a sample of five people. The results of this study are that the fostering of the achievement of the boccia cerebral palsy national altet in the Indonesian National Paralympic Committee is already in the good enough category but it is still not perfect.
\end{abstract}

Keywords

Boccia; cerebral palsy; coaching

\section{Introduction}

Achievement is a goal for all athletes, as we have known so far that the achievements of a normal athlete (not with special needs) are influenced by various factors especially athletes with special needs or athletes with disabilities (Martin, 1999). Athlete coaching is one of the main factors and is very important for an athlete's achievement. A good coaching process must take place continuously and continuously, in other words coaching athletes are carried out in stages based on the capabilities of an athlete and must have targets so that achievement coaching is carried out properly. Athlete coaching can be done as early as possible so that the earlier the athlete is trained, the faster the achievement will be achieved. Harsono (1998) said "aspects of sports training consist of 4 aspects, namely: aspects of physical training, aspects of technical training, aspects of tactics training, and aspects of mental training". The four aspects above are important points that must be known and mastered in coaching an athlete, especially athletes with special needs.

Sports for athletes with special needs have many benefits including improving quality of life, increasing endurance and strength, increasing brain performance, and restoring the mind. These sports also play a role in aspects of increasing honesty, sportsmanship, discipline, and education. For this reason the sport for physical disability was first introduced by Sir Ludwig Guttmann at the Stoke Mandeville Hospital in Jakarta 
in 1948 called the Stoke Mandeville Games (SMG) which continues today as the International Stoke Mandeville Games (Skaggs \& Hooper, 1996). According to Van der Woud, et al (1989), despite having a healthy body and personality with disabilities, they remain focused on quality of life and well-being.

Sports athletes with special needs in the world also have organizing events, such as: (1) For the Southeast Asian level called Asean Para Games which takes place and is held in conjunction with the implementation of the SEA Games; (2) For the Asian level it is called Asian Para Games which are held in connection with the holding of Asian games; (3) For the world level it is called Paralympic Games which takes place and is held at the same time as the Olympics. Of the multi events that are owned by sports with disabilities, it can be interpreted that the National Paralympic Committee of Indonesia (NPCI) must be a top priority as well as normal sports, because it involves the dignity of the nation.

The relevant social context determines which categorization seems most suitable to provide a meaningful organization (Saragih et al 2019). The organization that houses athletes with special needs in Indonesian territory is the Indonesian National Paralympic Committee (NPCI). NPCI comes from an international organization called the International Paralympic Committee (IPC). The National Paralympic Committee (NPC) is a sports organization for athletes with disabilities in a country. According to data from npcindonesia.id, NPCI has the initial name YPOC (Disability Sports Development Foundation). YPOC was formed by Prof. Dr. Soeharso on October 31, 1992 was based on the large number of Indonesian people with physical disabilities due to the effects of war and polio conditions that were endemic at that time. At that time the budget or source of funds was not yet clear, so the YPOC was formed so that the funding was clear. In 1996 YPOC was no longer under the auspices of KONI (Indonesian National Sports Committee) but under the auspices of the social minister so that the YPOC was still involved in rehabilitation sports and had not been included in disability sports, this resulted in YPOC not developing. Due to constraints in the form of a budget and still under the auspices of the social ministry, KONI suggested that YPOC change its name to BPOC so that it would be directly under the auspices of KONI so that funding would be clearer. Then at the National Sports Conference in West Java on December 15, 1993, YPOC was changed to BPOC (Sports Disability Guidance Board) directly under the auspices of KONI and funding was a little clearer but still in the rehabilitation sports category. In line with the times, IPC (International Paralympic Committee) established the rules "all organizations that are members of IPC must use the word paralympic". Because of this regulation, on August 30, 2010 the BPOC was changed to the Indonesian NPC (National Paralympic Committee) to date.

Boccia is a precision sport that requires athletes to have excellent coordination and movement control abilities. When viewed in terms of normal people (not special needs) this sport is a sport that is very easy to do. But at this boccia sport only athletes have disorders such as spasticity (stiffness), ataxia (impaired coordination and balance), atetosis (impaired movement and balance) and other conditions that cause limitations in coordination. Boccia is a sport that is played by two athletes or two groups of athletes (teams) by placing the ball (red or blue) as close as possible to the target ball (white) called pallina. Then the athlete throws the ball which has been given or determined by the referee before the match takes place as close as possible to the pallina in turn. The ball closest to Pallina gets points. Each loyal team set of matches is given 6 balls (BISFed, 2017).

Boccia athletes are classified into 4, namely $\mathrm{BC} 1, \mathrm{BC} 2, \mathrm{BC} 3$, and $\mathrm{BC} 4$. The $\mathrm{BC} 1, \mathrm{BC} 2$, and $\mathrm{BC} 3$ classifications are specifically for athletes with a medical diagnosis of cerebral palsy (CP), while BC4 is for athletes with non-cerebral palsy conditions. In this study, researchers only discussed the formation of boccia athletes' achievements with cerebral palsy. Cerebral 
palsy is a non-progressive brain disorder that causes developmental disorders in the brain. The brain is a very important organ because the brain regulates and controls all bodily functions such as the muscles that produce movement. In this disorder, injury or malformation occurs in the development of the central nervous system that affects the development of motor function and posture before birth, at birth or after birth. The term "cerebral" means the brain and "Palsy" means lack of control of the muscles. Problems associated with Cerebral Palsy in children involve muscle weakness, instability of movement (impaired coordination), impaired balance and slow response, with symptoms ranging from mild to severe. In the case of mild cerebral palsy, the child experiences a disruption in one limb and this problem may be almost invisible, whereas in severe cerebral palsy, the child has difficulty in carrying out daily activities and maintaining movement, posture and neuromuscular control so that sometimes it causes epileptic disorders, osteoporosis , dysphagia and others (Rana, et al, 2017).

Furthermore according to Boccia International Sport Federation, abbreviated as BISFed (2018), explained that BC1 is an athlete with a medium limitation condition, an athlete with cerebral palsy condition characterized by limited movement in the trunk muscles and poor balance when sitting but able to throw the ball, usually overhandedly. BC2 is an athlete with the mildest ability limitation, a cerebral palsy athlete who has a better sitting balance than $\mathrm{BC} 1$ athletes and can usually pick up or lift the ball from the floor and throw properly. BC3 is an athlete with the most limited ability condition, that is, a cerebral palsy athlete who is unable to hold and release the ball, therefore it is permissible to use rumps and assistants during the competition. And BC4 is an athlete with severe physical disability with diagnoses other than cerebral palsy, such as progressive muscular dystrophy and other physical disabilities. These sports have been organized since 2013 by the Boccia International Sport Federation (BISFed). Boccia matches require great tactical skills and concentration by players, the ability to analyze games, and also good accuracy. But not many scientific studies exist in this sports literature. Two possible reasons for this are the progressive loss of athletes with high support needs (the most severe disruption) from major sporting events such as Paralympic Games and lack of interest in the scientific community in minority groups (Reina, et al, 2018).

According to observations with the national coach of Indonesian boccia athletes at the Boccia sports hall, the number of Indonesian Cerebral Palsy boccia athletes is only seven. With a small number of athletes and not yet this branch of sports was born in Indonesia but has produced achievements at the international level. This is the background of researchers to conduct research to find out the development of Indonesian national cerebral palsy Boccia athletes conducted by the Indonesian National Paralympic Committee at this time.

\section{Research Methods}

This study uses qualitative research methods conducted in two places, at the head office of the Indonesian NPC (National Paralympic Committee) which is located at Jln. Ir. Sutami No. 86, Jurug, Surakarta, Central Java and the Indonesian Athletic Cerebral Palsy Athletic Building which is located at Jln. Captain Mulyadi, Kec. Pasar Kliwon, Surakarta, Central Java in March 2020. Data collection techniques in this study used interviews, observation, and documents. The interview technique was carried out to the chairperson of the Indonesian National Paralympic Committee sports department, the coordinator of the Indonesian boccia sport branch, the Indonesian boccia athletes coach, and the Indonesian athcia cerebral palsy national athlete. The technique of observation and document analysis is carried out within one month when the training camp takes place, which is every Monday to Friday. Data 
validity test used is source triangulation and method triangulation. The technique of taking research subjects with purposive sampling with a total of five people and data analysis techniques begins with the stage of the data reduction procedure, continued with the presentation of data, and ends with drawing conclusions. While the research procedures go through three stages: preparation, implementation, and closing with the preparation of the report.

\section{Discussion}

All branches of competition sports have the same goal that is achievement. Achievement becomes a benchmark for a coaching to run and develop well. Achievement is an achievement to be proud of, even though we all know that the process is no less important. But still good results are the hope of every competition sport. Ningsih (2018) states Competition in a very tight working world exposes organizations to strong efficiency and competitiveness. To improve efficiency, among others required Human Resources (HR) quality. The most important resource in an organization is the human resources, the people who provide the energy, talents, creativity and their efforts to the organization for an organization. Of course, to get a proud achievement is not easy, it requires early, special, tiered and sustainable coaching and good management of management from the organization or school therein (Sulaiman, 2020). This study aims to determine the development of the national athlete boccia cerebral palsy in the National Paralympic Committee of Indonesia. As we discussed a little about boccia above, boccia is a paralympic sport in the NPCI organization. Unlike the case with non-paralympic sports (normal sports), the development of boccia cerebral palsy sports should be done more thoroughly than non-paralympic sports. Looking at the factors of the condition of athletes who experience brain damage with a diagnosis of cerebral palsy, it does not mean that athletes are not capable of being given guidance.

All athletes in the competition sports are entitled to get good, appropriate and adequate achievement coaching. Because fostering achievement underlies the achievement of an achievement. According to Miftah (1997) coaching is a way or effort that is carried out continuously and gradually to achieve something that is desired. With the opinion of the experts above I can conclude that fostering achievement is an effort made by a group of teams with the aim to produce athletes' achievements which are carried out routinely, gradually, and intensively.

Performance coaching certainly has factors that influence so that achievement coaching runs smoothly and develops. The three stages above are at the same time a factor influencing the achievement of athletes. According to Kasimo (1991) the factors that influence the stage of fostering achievement are divided into two parts, namely: (1) endogenous factors are factors that originate from within themselves such as strength, speed, physical ability, endurance and others. In fostering the achievement of athletes who become endogenous factors are athletes; (2) exogenous factors are factors originating from outside that affect endogenous factors, if exogenous factors are adequate then endogenous factors will be easier to undergo achievement coaching. In fostering the achievements of athletes who become exogenous factors are the organization, the coach, the support team, facilities and infrastructure.

Certainly in a sports coaching must have endogenous factors, namely athletes, the difference is the reason behind these athletes joining the national athlete boccia cerebral palsy Indonesia. This is important because it relates to the motivation and personal goals of athletes. The noble aim will give good results, according to the results of interviews 
conducted with six Boccia cerebral palsy athletes consisting of: two $\mathrm{BC} 1$ athletes, two $\mathrm{BC} 2$ athletes, and two BC3 altets with male and female sexes. The goals and motivations to become a national athlete boccia cerebral palsy include: (1) of their own volition; (2) wants to participate in defending the country; (3) want to boast of parents and family; (4) wants to help the family economy; (5) want to have achievements and (5) want to experience the world of sports. It can be concluded that Indonesian athlete Cerebral Palsy Indonesia has a high sense of national defense, strong determination, high motivation, noble goals, and good independence. The goals and motivations of the boccia cerebral palsy national athletes greatly affect the results of coaching, naturally it is not long before they have produced achievements for the NPCI. In other words, endogenous factors in the coaching of national athlete boccia cerebral palsy in NPCI are sufficient.

Exogenous factors in fostering the achievements of the national athlete boccia cerebral palsy in the NPCI are the first organization, the NPCI organization is the parent of the branch of boccia cerebral palsy in Indonesia. NPCI has a large role in the coaching of Indonesian boccia cerebral palsy national athletes. NPCI has a duty to facilitate, control, and coordinate the development of Indonesian national cerebral palsy boccia athletes. In this case, the NPCI is in direct contact with the coordinator of the Boccia sports branch for all administration in the coaching of the Indonesian Boccia Cerebral Palsy national athlete. According to interviews with the head of the NPCI sports department and the coordinator of the sports branch in Boccia, all this time the relationship went smoothly and there were no problems that could not be resolved, because communication was always routinely carried out from both parties concerned. The second exogenous factor is the coach and the support team (doctors, psychologists, nutritionists, etc.), the trainer and the support team are under the coordinator of the Boccia sport.

According to the results of interviews and observations to the coach of boccia cerebral palsy athletes namely coach $\mathrm{BC} 1, \mathrm{BC} 2$, and $\mathrm{BC} 3$, the entire routine training process that is carried out every day at PELATNAS is carried out by the coach and the support team. The support team is not present every day, the support team comes when needed. For example when there are new athletes who want to join the National Training Board, the examination of $\mathrm{BC}$ athletes while determining the classification of athletes is determined directly by the orthopedic doctor who has been prepared by the NPCI. This proves that the coaches and support teams on the formation of Indonesian national athlete Boccia Cerebral Palsy already exist and have carried out tasks according to their respective portions.

The next factor is facilities and infrastructure, without good facilities and infrastructure, the process of developing Indonesian national athlete boccia cerebral palsy cannot run properly. Quality is important in any case, including facilities and infrastructure. Quality sports facilities and infrastructure is a factor in fostering good sports performance, therefore we need to create quality facilities and infrastructure. According to Soepartono (2000), facilities are defined as facilities, which are media used to facilitate a sporting performance development activity in the form of tools that will be used in the process of developing national athletes boccia cerebral palsy, namely wheelchairs, glasses, goalposts, rumps, and other aids. While the infrastructure is a supporter for ongoing development activities in the form of buildings or places that are used for the national athletic formation process boccia cerebral palsy.

From the information above, it can be concluded that facilities and infrastructure are one thing that cannot be separated from one another. Without adequate facilities and infrastructure the process of fostering achievement will not be carried out properly, therefore we need to pay attention to the quality of facilities and infrastructure that is in accordance with the needs so that the process of the national athlete Boccia Cerebral Palsy training 
process runs smoothly and well. According to the results of interviews and observations with national coaches and athletes at boccia cerebral palsy Indonesia, as long as at PELATNAS all needs are met and more than enough. Starting from lodging, transportation, food, vitamin intake, training equipment, and sports hall, everything is adequate as needed. The coordinator of the sports branch and the boccia cerebral palsy Indonesia coach also said that the process of procurement of goods needed was in accordance with needs. It can be concluded that the exogenous factor in coaching the national athlete boccia cerebral palsy in NPCI is complete and adequate.

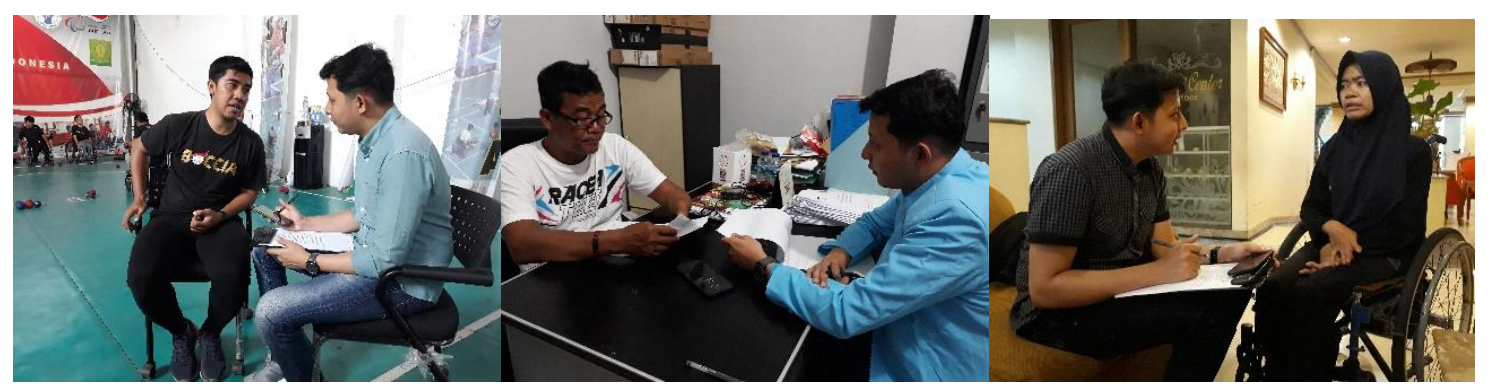

Figure 1. The Process of Interview
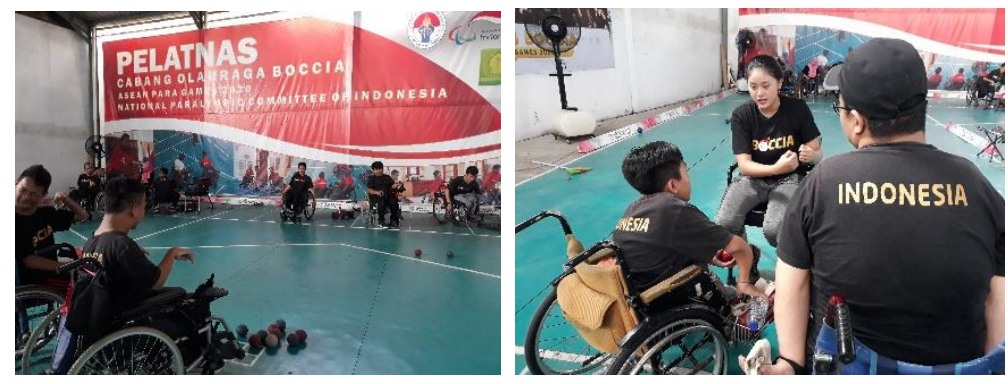

Figure 2. The Process of Observation

Athletes are the result of coaching conducted by coaches, athletes become the main human resources who will be trained to achieve an achievement. According to Menpora data (1997) champion athletes are produced by the collaboration between the coaching process and athletes with a percentage ratio of coaching $40 \%$ and athletes $60 \%$, meaning athletes contribute a greater percentage in achievement. According to Irianto (2002) good athletes must go through a good selection process, indicators in the selection of good athletes, namely: (1) health checks include: heart, cardiorespiration, nervous system and muscles; (2) anthropometry includes: height, weight, and body circumference; (3) physical abilities include: endurance, speed, and strength, (4) psychological abilities include: attitudes and motivation; (5) offspring; (6) length of time for training and; (7) maturity in coaching. The seven indicators above must be considered in selecting athletes. According to interviews conducted with the coordinator of the sports branch and the coach of the cerebral palsy boccia at the Sports Center boccia, all national athletes of the boccia cerebral palsy who will join PELATNAS through the process of health checks, height, weight, physical ability tests, and interviews related to sports branches boccia cerebral palsy. This is not in line with the opinions of the experts above, the seven indicators should really be implemented so that the composition of athletes from the beginning of recruitment is known and simplifies the training process. Molla (2019) states education is a key of life. It is the formal and informal processes of teaching and learning used to develop a person's knowledge, skills, attitudes, understanding, etc., in a certain area or domain. Athlete achievement according to the Ministry of National Education (2000) is influenced by four aspects, namely: (1) athlete's 
personality; (2) the athlete's physical condition; (3) athlete's mental abilities; and (4) tactical and tactical skills. To produce good athletes must begin with a good selection process, because athletes are endogenous factors to produce achievements. Broadly speaking, the NPCI's recruitment process for the national athlete Boccia Cerebral Palsy is quite good because it has done four indicators, but in my opinion this needs to be improved and evaluated.

Another important factor explained by Harsono (1998) is "the athlete's trust in the coach", this is important because if it is achieved then the process of fostering athlete achievement is effective. Another opinion put forward by Kasimo (1991) a coach is said to be good if able: (1) evaluating athletes; (2) have courage in making decisions; (3) creating an attitude of authority; (4) have a sportsmanship; (5) give a good and right example; (6) has experience that will help the introspection process of an exercise program; (7) has the determination to win; (8) provides an appropriate and reasonable response to the results achieved; (9) has a little sense of humor so that training does not take place tense; (10) social at heart; (11) maintaining a healthy body condition; (12) has a leadership spirit.

According to the results of interviews with the coordinator of the national sports and athletes branch of boccia cerebral palsy, the national athlete coach boccia cerebral palsy in the training process always provides information and advice clearly. All Boccia Cerebral Palsy national athlete trainers are graduates of the sports sciences and sports training faculties. Although not all trainers, some trainers have participated in sports coaching, this proves that all national athlete coach Boccia Cerebral Palsy has undergone formal and nonformal education in accordance with the current profession. In the national athletic training process boccia cerebral palsy all trainers help one another and provide input by conducting regular discussions with fellow athletes so that the training process can run smoothly and optimally. According to the coordinator of the sports branch boccia cerebral palsy all trainers always come regularly when the training schedule is underway. All coaches are given responsibility for each athlete they coach, each athlete being coached must have physical, tactic, and mental progress or development. Evaluation of the results of training on the ability of athletes is carried out routinely every day and results are reported regularly every week to the coordinator of the branch of sports boccia cerebral palsy. Evaluation of the results of the athlete's training periodically is reported to aim to maintain and improve the appearance and abilities of the athlete so that the coaching process runs smoothly. Evaluation reports are the responsibility of each trainer, this will indirectly increase the responsibility of the trainer. Without the coach's authority, all athletes will not follow and obey all instructions from the coach. At PELATNAS boccia all national athletes of boccia cerebral palsy Indonesia follow and obey all commands given by the coach. The process of routine training, routine evaluation, training programs that have been clearly written, and coupled with the achievements that have been achieved by the Indonesian branch of boccia cerebral palsy, prove that the trainers in the training process are of high quality.

Table 1. Observation Results

\begin{tabular}{cll}
\hline No & \multicolumn{1}{c}{ Activities } & Yes \\
\hline 1 & The number of BC1 athletes is two people & $\sqrt{ }$ \\
\hline 2 & The number of BC2 athletes is three people & $\sqrt{ }$ \\
\hline 3 & The number of BC3 athletes is two people & $\sqrt{ }$ \\
\hline 4 & The number of BC1 coaches is two people & $\sqrt{ }$ \\
\hline 5 & The number of BC2 coaches is one people & $\sqrt{ }$ \\
\hline 6 & The number of BC3 coaches is one people & $\sqrt{ }$ \\
\hline 7 & Routine training is done every day (Monday-Friday) &
\end{tabular}




\begin{tabular}{|c|c|c|}
\hline 8 & $\begin{array}{l}\text { The process of evaluating the results of the exercise every day after } \\
\text { finishing the exercise }\end{array}$ & $\sqrt{ }$ \\
\hline 9 & Motivation to improve athlete mentality every Wednesday & $\sqrt{ }$ \\
\hline 10 & Refreshing to reduce boredom every 1 month on Saturdays & $\sqrt{ }$ \\
\hline 11 & $\begin{array}{l}\text { Complete athletes training equipment (field, wheelchair, rump, } \\
\text { ball, glasses, etc.) }\end{array}$ & $\sqrt{ }$ \\
\hline 12 & $\begin{array}{l}\text { Complete coaches training equipment (trainer chairs, clothes and } \\
\text { shoes) }\end{array}$ & $\sqrt{ }$ \\
\hline 13 & Data evaluation of athletes training per day & $\sqrt{ }$ \\
\hline 14 & The athlete's written exercise program during the competition & $\sqrt{ }$ \\
\hline 15 & Written athlete training schedule & $\sqrt{ }$ \\
\hline 16 & Three silver medals & $\sqrt{ }$ \\
\hline 17 & Three bronze medals & $\sqrt{ }$ \\
\hline 18 & Discussion of the evaluation of athlete's training results & $\sqrt{ }$ \\
\hline 19 & $\begin{array}{l}\text { Coach discussion with sports coordinator on athlete training } \\
\text { programs }\end{array}$ & $\sqrt{ }$ \\
\hline 20 & Transportation of coaches and athletes during the training process & $\sqrt{ }$ \\
\hline 21 & Residence of athletes and coaches during training camps & $\sqrt{ }$ \\
\hline
\end{tabular}

Organization becomes important in a sport. The organization has a duty to accommodate all the needs of a sport. Likewise in fostering the achievements of Indonesian bocebals palsy athcia athletes shaded by the National Paralympic Committee (NPC). Organizations must be clean and healthy in order to create a transparent atmosphere so that mutual expectations, namely achievements, can be achieved. Sutarto (2002) argues that organization is an element of mutual influence between people in groups who work together to achieve certain goals. So it can be concluded that the organization is a group of people who are in a container that plans, discusses, discusses and seeks solutions with the same goal. There are a number of factors that are factors in whether an organization is good or not, Sutarto (2002) said the form of the organization must be adjusted to the composition of the organization's officials in order to run effectively and efficiently. The organizational form is divided into eight, namely: (1) plural organizational forms; (2) a single form of organization; (3) the form of path organization; (4) functional organizational forms; (4) functional organizational form; (5) line and staff organizational forms; (6) functional and staff organizational forms; (7) functional organizational forms and pathways; (8) organizational forms of functional and staff lines.

From the information above, it is possible that an organization has more than one form of organization. NPCI uses two forms of organization namely a single and functional form of organization. This form of organization has been established since the early formation of the NPCI. Sutarto (2002) argues that a single form of organization is an organization headed by only one leader, and is usually referred to as the head or chairman. Whereas the form of functional organization is an organization whose authority is delegated to the part of the organizational unit under it and the leader has the right to give orders related to his field to the implementing members. In accordance with the results of interviews and documents with the head of the coordinating department of the sports branch of the NPCI that the NPCI has one general chairman who oversees several other chairs, namely: chairman of the organizational field, chairman of the field of achievement development, chair of the budget planning department, chair of the R\&D department, chair of the legal department and advocacy, chair of the regional empowerment department, chair of the sports department department, chair of the coach department, chair of the referees and competition department, 
chair of the disability classification department, chair of the foreign relations department, chair of the public relations department, and chair of the business and funding department. All NPCI department heads have the duty and responsibility to control provincial NPCs throughout Indonesia. Decisions must be made by the general chairperson in accordance with applicable regulations.

In addition to the form of organization other things that need to be considered elements in the organization are also important factors in the creation of a good organization. Sutarto (2002) states the elements in the organization are (1) management; (2) members; (3) statutes and bylaws; (4) work plan; and (5) budget. The five elements of the organization must be fulfilled and run with the existing provisions, so that the organization can facilitate a branch of sports properly. Since the inauguration of the NPCI in 2010, the NPCI has had all the elements in an organization, namely: management, members, statutes and bylaws, work plans and budgets. With the composition of the management and members that have been clear with their respective parts that have been determined according to needs with an official decree Number: 01 / NPC-Inna / SKEP / IV / 2019 this proves that the membership of the NPCI is clear.

\section{Conclusion}

All the sports development achievements expect the final results of achievement, as does the boccia sport. Evidenced by the achievements that have been generated at the international level at the ASIA regional competition held in Dubai in December 2019. Although the boccia sport was only introduced in Indonesia in 2017, in this competition the boccia sport produced three silver and three bronze medals. The longer the process of fostering achievement, the better the expected results. In accordance with the opinion of experts, NPCI has conducted a process of national athlete boccia cerebral palsy coaching with three processes namely: input, process, and output. The formation of the Boccia Cerebral Palsy national athlete in the NPCI certainly has a factor that influences the coaching process, this is in accordance with the opinions of experts. The first factor is endogenous factors, namely factors that come from within the athlete in the form of motivation and goals. National athlete boccia cerebral palsy has strong motivation and goals, and this fulfills the criteria for good endogenous factors. The second factor is the exogenous factor which is a factor originating from outside other than the national athlete boccia cerebral palsy. Exogenous factors are organization, trainers, support teams, facilities and infrastructure.

Athletes are the main human resources that will be trained by coaches. In addition to good motivation, the selection process that is in line with standards also influences the quality of the athlete. In accordance with the expert opinion that has been explained above athletes must go through a good selection process. But in NPCI the selection is not yet in accordance with the opinions of experts, so this will affect the quality of athletes. It can be concluded that the selection process for Boccia Cerebral Palsy national athletes who will join PELATNAS is quite good because it has done four indicators out of the seven indicators explained by experts. The coach is the teacher of an athlete, the quality of the coach greatly influences the achievements that will be generated by an athlete. All national athlete coach boccia cerebral palsy at NPCI are graduates of the faculty of sports science and sports training. During the training process of Boccia Cerebral Palsy national athletes, all trainers support each other and work together to improve the abilities of their respective athletes. The coach also always trains according to the time scheduled by the coordinator of the Boccia sport. I also got the same information from an athlete who said that the training process ran smoothly and was active every day. Plus the coach who does not get bored to always provide motivation every 
day and is equipped with motivation routinely once every week, to keep the spirit and mentality of the national athlete boccia cerebral palsy. The quality of the athlete is routinely controlled by each coach by conducting routine evaluations every day and overall evaluations every week, which will then be reported to the branch coordinator of the sports branch ofcia. The training program was also written and clearly defined by the coordinator of the Boccia sports branch since the initial training period. This is done to avoid mistakes and improve the appearance of each athlete. A quality training process will give results that are achievements, this is evidenced by the achievements that have been achieved by national athletes boccia cerebral palsy.

NPCI is an organization that facilitates sports with special needs in Indonesia at the international level. NPCI uses a single form of organization and functional, in accordance with the opinion of experts that a good organization has more than one form of organization. All decisions are made by the general chairman, and all parts of the coordinator will be controlled by each head of the department that has been determined. NPCI already has complete organizational elements, consisting of: management, members, statutes and bylaws, work plans, and budgets. This is reinforced by the finding of an official decree number: $01 /$ NPC-Inna / SKEP / IV / 2019 for each board and member. Based on the results of qualitative research using interviews, observations, and documents that I have done, in my opinion it can be summed up overall with the evidence and facts of the field that I got, that fostering the national altet performance of boccia cerebral palsy in the National Paralympic Committee of Indonesia is already quite good but still not perfect. As a suggestion, further evaluation is needed so that the development of the achievements of the Boccia Cerebral Palsy National Altet in the Indonesian National Paralympic Committee becomes better.

\section{References}

BISFed. 2018. Classification Rules - 3rd Edition

Depdiknas. 2000. Pendidikan Jasmani. Jakarta: Balai Pustaka.

Harsono. 1998. Coaching dan Aspek-aspek Psikologi dalam Coaching. Jakarta: Depdikbud, Dirjen Dikti.P2LPTK.

Irianto, Djoko Pekik. 2002. Dasar Kepelatihan. Yogyakarta: FIK UNY. Fakultas.

Martin, JJ. 1999. Perkembangan Pribadi Model Psikologi Olahraga untuk Atlet dengan Kecacatan. Jurnal Olahraga Terapan Psikologi, 11, 181-193. DOI: 10.1080/ 10413209908404199

Menpora, 1977. Kebijakan Pemerintah di Bidang Keolahragaan dalam Pembinaan Olahraga. Jakarta: Kantor Meneg Pemuda dan Olahraga.

Molla, Y. S. (2019). Upper Primary Learners' Level of Critical Thinking Skill and Its Effect on Students' English Language Achievement in Relation with Sex. Budapest International Research and Critics in Linguistics and Education (BirLE) Journal. 54-63.

Ningsih, S. (2018). The Relationship between Motivation and Worker's Productivity in Civil Registration and Population Department, Asahan Regency, Indonesia. Budapest International Research and Critics Institute-Journal (BIRCI-Journal), 148-160.

Rana Mahendra. 2017. A Systematic Review on Etiology, Epidemiology and Treatment of Cerebral Palsy. International Journal of Nutrition, Pharmacology, Neurological Desease, vol 7.

Reina, et al. 2018. Throwing distance constraints regarding kinematics and accuracy in highlevel boccia players. Journal of sport science and medicine, 33, 299-306. 
Saragih, Hisarma et al. 2019. The struggle of Batak Simalungun for their identity in Church organization in Simalungun, Medan, Indonesia. Journal of Human Behavior in the Social Environment, 693-704.

Skaggs, S., Hooper, C. 1996. Individuals with Visual Impairments: A review of psychomotor behavior. Adapted Physical Activity Quarterly, 13: 16-26

Suharno, H. P. 1985. Ilmu Kepelatihan Olahraga. Yogyakarta: IKIP Press.

Sulaiman, et al. (2020). The Evaluation of Athletic Extracurricular Management of Dr. Soetomo and Jalan Jawa Junior High School in Surabaya. Budapest International Research and Critics in Linguistics and Education (BirLE) Journal, 11-19.

Sutarto. 2002. Dasar-Dasar Organisasi. Yogyakarta: Gajah Mada Press.

Soepartono. 2000. Sarana dan Prasrana Olahraga. Jakarta: Depdiknas.

Van der Woude, L.H., Veeger, D., Rozendal, R.H. 1989. Ergonomics of Wheelchair Design:A Prerequisite for Optimum Wheelchair Conditions. Adapted Physical Activity Quarterly, 6: 109-132 